\title{
Influence of solar activity on ambient dose equivalent $H *(10)$ measured with thermoluminescent dosimeters in Slovenia
}

\author{
Benjamin Zorko, Matjaž Korun, Boštjan Črnič, Branko Vodenik, and Sandi Gobec \\ Jožef Stefan Institute, Ljubljana, Slovenia
}

[Received in August 2020; Similarity Check in August 2020; Accepted in February 2021]

Ambient dose equivalent $H^{*}(10)$ is measured to assess general population exposure to ionising radiation. From its spatial and time variations it is possible to identify sources of exposure. In Slovenia, semi-annual $H^{*}(10)$ is measured routinely with thermoluminescence dosimeters at 66 locations around the Nuclear Power Plant (NPP) Krško and at 50 other locations covering the rest of Slovenian territory. Since the Chernobyl accident contamination had ceased to contribute to ambient dose equivalents, we have been calculating correlation coefficients between annual mean number of sunspots and annual $H^{*}(10)$. These correlation coefficients were calculated for five locations in western Slovenia and for five annual $H^{*}(10)$ extracted from measurements around NPP Krško. Their ranges between -0.64 and -0.38 suggest a clear negative correlation between solar activity and $H^{*}(10)$. Mean annual $H^{*}(10)$ averted by solar activity in the past two solar maxima reached $0.070 \mathrm{mSv}$ around NPP Krško (155 m.a.s.1.) and $0.132 \mathrm{mSv}$ and $0.180 \mathrm{mSv}$ at Kredarica (2515 m.a.s.1.). Quantifying the influence of the solar activity on the ambient dose equivalent helps us to better understand exposure of the general population to ionising radiation.

KEY WORDS: averted ambient dose equivalent; Chernobyl contamination; correlation coefficient; cosmic rays; soil radioactivity; solar cycle

Articles 35 and 36 of the EURATOM treaty (1) require from the European Union (EU) member states to monitor continuously the levels of environmental radioactivity, which is carried out in line with the Safety Standards Series No. RS-G-1.8 issued by the International Atomic Energy Agency (IAEA) (2). These include networks of thermoluminescence (TL) dosimeters measuring the ambient dose equivalent $H^{*}(10)$ of external ionising radiation around nuclear facilities to provide radiation safety information for workers and nearby population (3). They can also cover a larger territory to provide environmental radiation exposure information for the general public (4, 5). Such dosimeters are placed outdoors at a height of $1 \mathrm{~m}$ above ground to minimise the influence of variations in soil radioactivity (6).

Slovenia has two such networks. One comprises $66 \mathrm{TL}$ dosimeters covering the $10 \mathrm{~km}$ perimeter around the Nuclear Power Plant (NPP) Krško reactor. The other consists of 50 TL dosimeters to cover the rest of the Slovenian territory (7). Both networks are run according to the Ionising Radiation Protection and Nuclear Safety Act (8) and the Rules on the Monitoring of Radioactivity (7).

The dosimeters are mainly exposed to ionising radiation from secondary cosmic rays (9), which are generated in the stratosphere and the upper troposphere by primary cosmic

Corresponding author: Benjamin Zorko, Jožef Stefan Institute, Jamova cesta 39, 1000 Ljubljana, Slovenia, E-mail: benjamin.zorko@ijs.si rays, and to gamma rays originating from radioactivity in the soil. Since the Chernobyl contamination has ceased to contribute to soil radioactivity, it has been nearly constant, with small variations owed to meteorological conditions. Namely, rain may increase it through the washout of radon daughters from the atmosphere (11) and snow may reduce with its cover. In other words, the contribution of natural radioactivity from soil to the annual exposure varies, but this variation does not affect semi-annual or annual measurements. The dose rate from cosmic rays, in turn, reflects the periodicity of solar activity, also known as the solar cycle (12). Annual solar activity is measured with annual mean number of sunspots (13) as a directly observed quantity. The aim of our study was to evidence that measured ambient annual dose equivalent $H^{*}(10)$ negatively correlates with the number of sunspots occurring over that same year.

\section{MATERIALS AND METHODS}

\section{TL dosimeters}

Environmental radiation dosimeters are designed to contain two $0.5 \mathrm{~mm}$ thick TL pellets of $5 \mathrm{~mm}$ diameter (6). They are placed on the top of a white plastic bottle, which is hung at $1.0 \mathrm{~m}$ above the ground. The luminescent material is $\mathrm{CaF}_{2}$ doped with $\mathrm{Mn}$, which is produced by the Jožef Stefan Institute (JSI), Ljubljana, Slovenia (14). 
Since these TL dosimeters are insensitive to neutrons, only charged particles and photons contribute to the measured ambient dose. Therefore, the total annual dose equivalent $H^{*}(10)$ measured by TL does not include the dose contribution from neutrons.

Dosimeters are read with an in-house system IJS MR $200 \mathrm{C}$. The sensitivity of the measurements is $5 \mu \mathrm{Sv}$ and standard deviation under repeatable conditions $0.020 \mathrm{mSv}$ at a dose of $0.40 \mathrm{mSv}(6)$. The dosimeters have been type tested in the energy range from $40 \mathrm{keV}$ to $1.2 \mathrm{MeV}$ at the Laboratory for Dosimetry Standards of JSI, which is accredited by Slovenian Accreditation (15). As all dosimeters are calibrated individually, the uncertainty of the calibration constant is $5 \%$ for individual component, and $2.5 \%$ for the calibration field. The dosimeters are annealed by heating the pellets to $350^{\circ} \mathrm{C}$.

\section{Exposure conditions}

Our TL dosimeters are exposed at about $1 \mathrm{~m}$ above ground twice a year, from January to June and then from July to December. They are distributed to cover open terrain and rural and urban environments. The obtained annual ambient dose equivalents are the sum of semi-annual dose measurements.

Their reproducibility can be assessed from the scattering of semi-annual measurements at nine locations along the fence of the NPP Krško, 150-350 m from the reactor axis, under the assumption that all dosimeters there receive the same dose. This assumption stems from the fact that they are all positioned where soil is replaced by limestone gravel. The dispersion of dose rate equivalents measured during the same time interval is $5.9 \%$ (16). This dispersion corresponds to the $5 \%$ uncertainty of individual calibration constants.

\section{Calculation of ambient dose equivalent from cosmic rays}

Mean annual ambient dose equivalents from secondary cosmic rays were calculated with the Excel-based Program for calculating Atmospheric Cosmic-ray Spectrum (EXPACS) (17-19). It calculates fluxes of secondary cosmic rays, mainly of neutrons, electrons, and photons at a specified point in the atmosphere from the galactic (primary) cosmic rays and solar data (17). From these fluxes it calculates the effective dose, ambient dose equivalent, and absorbed dose in the air (17-19) taking into account the surrounding environment. For the surrounding environment, the "Ground" option was chosen with the water fraction of 0.2 .

\section{Calculation of correlation coefficients}

To assess quantitatively the influence of solar activity on ambient dose equivalent it is necessary to correlate it with the contribution of cosmic rays to ambient dose equivalent using the following equation:

$r\left[H^{*}(10), n\right]=\frac{\frac{1}{i_{\max }-i_{\min }+1} \sum_{i=i_{\min }}^{i_{\max }}\left[H^{*}(10)_{i}-\overline{H^{*}(10)}\right] \cdot\left[n_{i}-\bar{n}\right]}{\sigma\left[H^{*}(10)\right] \cdot \sigma[n]}$

where $r$ stands for correlation coefficient, $i_{\text {min }}$ and $i_{\max }$ for the first and the last year of the time interval under investigation, respectively, $H^{*}(10)_{\mathrm{i}}$ and $n_{\mathrm{i}}$ for ambient dose equivalent and mean number of sunspots over the year $i$, respectively, $\overline{H^{*}(10)}$ and $\bar{n}$ for mean annual ambient dose equivalent and mean annual sunspot number over the time interval $\left(i_{\text {min }}-i_{\text {max }}\right)$, and $\sigma\left[H^{*}(10)\right]$ and $\sigma(n)$ for the dispersion of ambient dose equivalents and the number of sunspots over the observed period, respectively. To evaluate the correlation coefficient, it is important to choose the time interval over which Chernobyl contamination does not

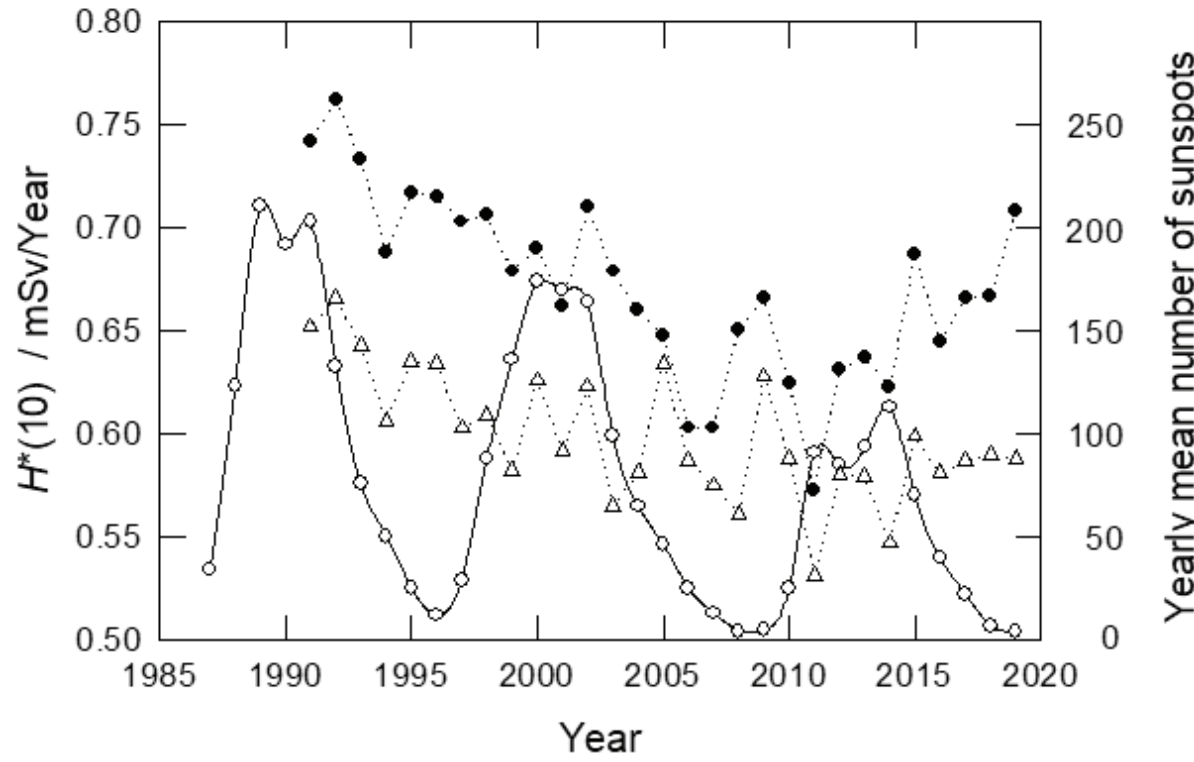

Figure 1 Annual ambient dose equivalent $H^{*}(10)$ averaged over nine locations at the fence of NPP Krško (155 m.a.s.l., white triangles) and over three locations in the nearby town of Krško (black dots) and annual number of sunspots (white dots) (13) 
interfere with the solar cycle, that is, when its influence on ambient dose equivalent is lower than annual dose equivalent fluctuations. Therefore, the first year $i_{\min }$ starts with local ambient dose equivalent minimum, after which dose equivalent starts to rise, which is a trend opposite to the decreasing trend of Chernobyl contamination. This criterion removes the influence of the Chernobyl contamination. For the last year of the time interval, $i_{\max }$, we took 2019 for all measurements.

\section{RESULTS AND DISCUSSION}

Figures 1-3 show typical fluctuations in ambient dose equivalents and number of sunspots over time. Annual ambient dose equivalents in all three segments exhibit a decreasing trend since $i_{\text {min }}$, except for $H^{*}(10)$ measured at Sečovlje. Here the fallout of ${ }^{137} \mathrm{Cs}$ was below the detection limit, i.e. $10 \mathrm{kBq} / \mathrm{m}^{2}$ in 1986 and below $3 \mathrm{kBq} / \mathrm{m}^{2}$ in 1996 and did not influence ambient dose equivalent (20). What the figures clearly show is that ambient dose equivalents tend to exhibit a negative correlation with the number of sunspots, i.e. solar activity: $H^{*}(10)$ drops when solar activity is rising and rises when solar activity is dropping.

Table 1 shows mean ambient dose equivalents around NPP Krško and the rest of Slovenia as well as the contribution from the secondary cosmic rays calculated with the EXPACS software for the elevation of 155 m.a.s.l., corresponding to the elevation of NPP Krško. All these measurements exclude the contribution of the neutron component, as TL dosimeters cannot detect it.

Table 2 shows correlation coefficients between annual mean number of sunspots and annual $H^{*}(10)$ at five locations in western Slovenia and around NPP Krško as well as the beginning $i_{\min }$ of the time interval from which the coefficients were calculated $\left(i_{\max }\right.$ was 2019 for all). The correlation was always negative, which indicates a consistent influence of solar activity on ambient dose equivalent. Table 2 also clearly shows that correlation coefficients decrease with elevation above sea level. Measurements at Sečovlje show higher correlation coefficients even though $H^{*}(10)$ from cosmic rays was the lowest, because the time interval used in the calculation is longer due to low Chernobyl contamination at this location (20) and because it partly overlaps with the time interval of the solar activity around 1990.

\section{Interpretation of the findings}

The uncertainties of the means correspond to the dispersion of the readings under reproducible conditions of both semi-annual measurements $(0.030 \mathrm{mSv}$ at a value of the indication corresponding to the dose $0.4 \mathrm{mSv}$ ) averaged over the locations. Only the uncertainties due to the

Table 1 Mean annual ambient dose equivalents $H^{*}(10)$ measured around NPP Krško, and the rest of Slovenia, and calculated contribution of cosmic rays, from 2002 to 2019 . The uncertainties of the measured values are $7.5 \%$ and correspond to the expanded uncertainty due to the standard deviations of the indications of both semi-annual measurements

\begin{tabular}{llll}
\hline Year & $\begin{array}{c}\boldsymbol{H}^{*}(\mathbf{1 0})_{\text {NPP }} \\
(\mathbf{m S v})\end{array}$ & $\begin{array}{c}\boldsymbol{H}^{*}(\mathbf{1 0})_{\text {rSlovenia }} \\
(\mathbf{m S v})\end{array}$ & $\begin{array}{c}\boldsymbol{H}^{*}(\mathbf{1 0})_{\text {cosmic rays }} \\
(\mathbf{m S v})\end{array}$ \\
\hline 2002 & 0.791 & 0.792 & 0.297 \\
\hline 2003 & 0.769 & 0.791 & 0.297 \\
\hline 2004 & 0.765 & 0.793 & 0.279 \\
\hline 2005 & 0.827 & 0.864 & 0.302 \\
\hline 2006 & 0.783 & 0.846 & 0.310 \\
\hline 2007 & 0.766 & 0.840 & 0.314 \\
\hline 2008 & 0.822 & 0.868 & 0.314 \\
\hline 2009 & 0.837 & 0.922 & 0.317 \\
\hline 2011 & 0.793 & 0.886 & 0.317 \\
\hline 2012 & 0.738 & 0.899 & 0.315 \\
\hline 2013 & 0.806 & 0.881 & 0.313 \\
\hline 2014 & 0.803 & 0.877 & 0.311 \\
\hline 2015 & 0.763 & 0.849 & 0.305 \\
\hline 2016 & 0.829 & 0.895 & 0.306 \\
\hline 2017 & 0.814 & 0.902 & 0.311 \\
\hline 2018 & 0.823 & 0.895 & 0.316 \\
\hline 2019 & 0.829 & 0.870 & 0.316 \\
\hline
\end{tabular}

cosmic rays - calculated contribution of the secondary cosmic rays; NPP - measurements around the Nuclear Power Plant Krško; rSlovenia - measurements in the rest of Slovenia 


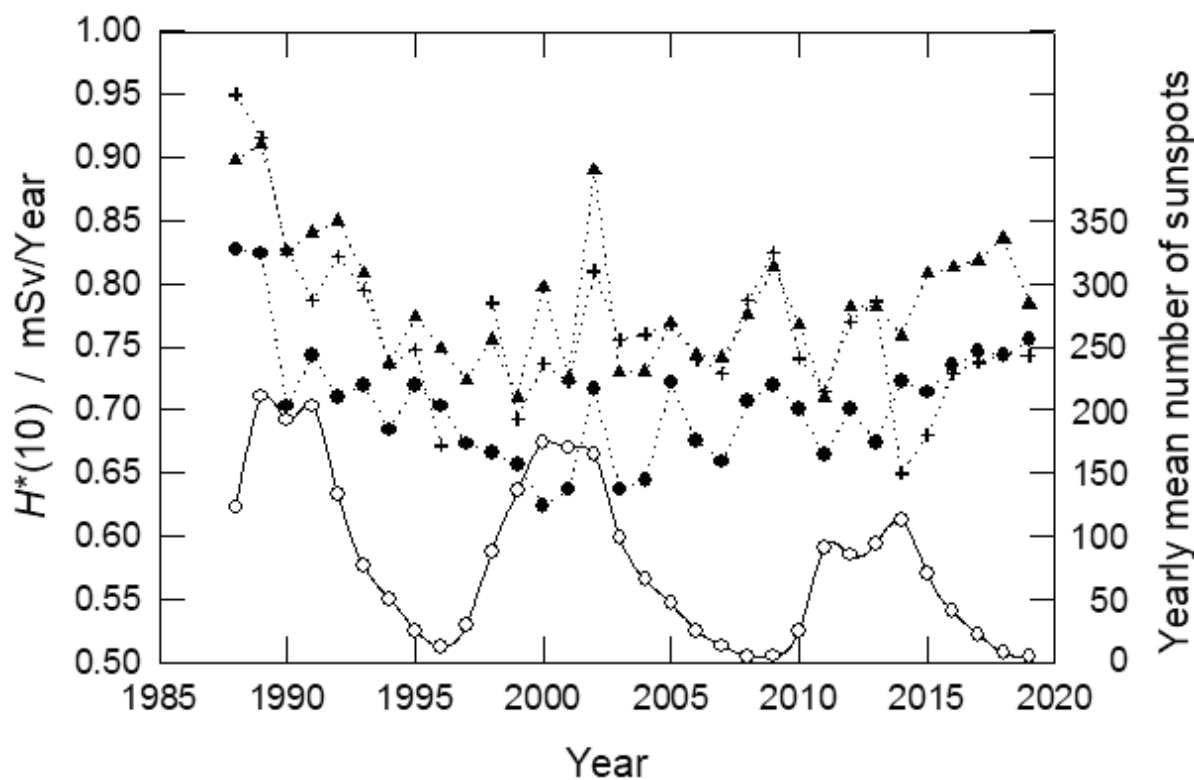

Figure 2 Annual ambient dose equivalent $H^{*}(10)$ at the locations Kusova Vrbina (black dots), Amerika (triangles), and Gmajnice (crosses) near NPP Krško, and the annual number of sunspots (white dots) (13)

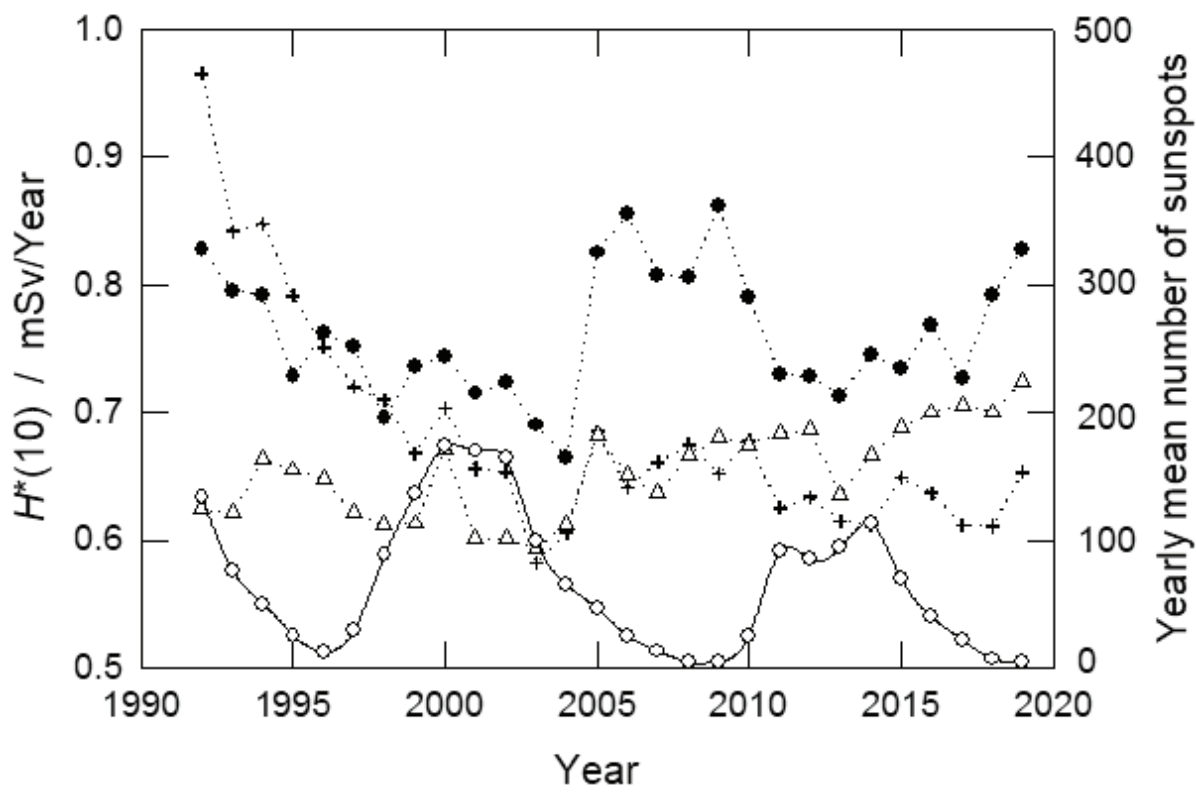

Figure 3 Annual ambient dose equivalent $H^{*}(10)$ at three locations in western Slovenia: Kredarica (2515 m.a.s.1., black dots), Trenta (624 m.a.s.l., crosses), and Sečovlje (2 m.a.s.l., triangles) and the annual number of sunspots (white dots)

Table 2 Correlation between annual mean number of sunspots $(n)$, and annual ambient dose equivalent $\left[H^{*}(10)\right]$ measured around NPP Krško (at 155 m.a.s.l.) and five locations in western Slovenia (Kredarica, Trenta, Stara Fužina, Bilje, and Sečovlje)

\begin{tabular}{lcclcc} 
Location & $\boldsymbol{r}\left[\boldsymbol{H}^{*}(\mathbf{1 0}), \boldsymbol{n}\right]$ & $\boldsymbol{i}_{\min }$ & \multicolumn{1}{c}{ Location } & $\boldsymbol{r}\left[\boldsymbol{H}^{*}(\mathbf{1 0}), \boldsymbol{n}\right]$ & $\boldsymbol{i}_{\min }$ \\
\hline $\begin{array}{l}\text { NPP fence, mean value over } \\
\text { nine locations }\end{array}$ & -0.28 & 2006 & Kredarica, 2515 m.a.s.1. & -0.69 & 2004 \\
\hline $\begin{array}{l}\text { Krško mean value over three } \\
\text { locations }\end{array}$ & -0.46 & 2006 & Trenta, 624 m.a.s.l. & -0.55 & 2003 \\
\hline Kusova Vrbina & -0.54 & 2000 & Stara Fužina, 547 m.a.s.1. & -0.53 & 2008 \\
\hline Amerika & -0.44 & 2003 & Bilje, 55 m.a.s.1. & -0.38 & 1995 \\
\hline Gmajnice & -0.38 & 2003 & Sečovlje, 2 m.a.s.l & -0.52 & 1992 \\
\hline
\end{tabular}

$i_{\min }-$ the start of the time interval where the correlation coefficient was calculated; m.a.s.l. - metres above sea level 
individual component of the calibration factor of the detectors are included in the analysis here; the uncertainty of the calibrating field is not considered, since it does not affect $H^{*}(10)$.

Table 1 shows that mean annual dose equivalents during the lowest solar activity (around 2019 and 2009) were the highest: $0.833 \pm 0.062$ and $0.837 \pm 0.063 \mathrm{mSv}$, respectively around NPP Krško and $0.910 \pm 0.068$ and $0.922 \pm 0.069 \mathrm{mSv}$, respectively in the rest of Slovenia. At the highest solar activity around 2014 and 2002, annual $H^{*}(10)$ around NPP Krško was $0.763 \pm 0.057$ and $0.765 \pm 0.057 \mathrm{mSv}$, respectively, whereas in the rest of Slovenia it was $0.849 \pm 0.046$ and $0.791 \pm 0.059 \mathrm{mSv}$, respectively. The lowest $H^{*}(10)$ values corresponding to the highest solar activity in 2002 were measured as late as 2004 , most probably because of the influence of the residual contamination with the Chernobyl fallout, which increased dose equivalents in 2002 and 2003, so the minimum tends to be overestimated. From the maxima measured in 2009 and 2019 it follows that the highest $H^{*}(10)$ corresponding to no sunspots is $0.835 \pm 0.045 \mathrm{mSv}$ for NPP Krško and $0.916 \pm 0.048 \mathrm{mSv}$ for the rest of Slovenia. Maximal annual $H^{*}(10)$ averted by the solar activity is calculated as the difference between the maximal $H^{*}(10)$ and the minimum measured when the solar activity is maximal. During the 2014 solar maximum, the averted $H^{*}(10)$ at NPP Krško and the rest of Slovenia was $0.072 \pm 0.073$ and $0.067 \pm 0.066 \mathrm{mSv}$, respectively, whereas during the 2003 solar maximum, it was $0.070 \pm 0.073$ and $0.125 \pm 0.077 \mathrm{mSv}$, respectively.

On the other hand, $H^{*}(10)$ due to secondary cosmic rays excluding neutrons was 0.316 and $0.317 \mathrm{mSv}$ at 155 m.a.s.l. during the solar minimum in 2019 and 2009, respectively and 0.305 and $0.297 \mathrm{mSv}$ during the solar maximum in 2014 and 2003, respectively. EXPACS calculations of the averted $H^{*}(10)$ at NPP Krško of 0.011 and $0.020 \mathrm{mSv}$ during the solar maximum of 2014 and 2003 , respectively is considerably lower than the averted $H^{*}(10)$ from TLD measurements.

A similar discrepancy can be observed for the measurements at Kredarica at the altitude of 2515 m.a.s.1.. Here the maximum annual ambient dose equivalents measured in 2019 and 2009 were $0.828 \pm 0.062$ and $0.862 \pm 0.065 \mathrm{mSv}$, respectively, and the minimum dose equivalents measured in 2014 and 2004 were $0.713 \pm 0.053$ and $0.665 \pm 0.050 \mathrm{mSv}$, respectively. Mean $H^{*}(10)$ corresponding to the quiet sun was $0.845 \pm 0.045 \mathrm{mSv}$, implying an averted dose equivalent of $0.132 \pm 0.070 \mathrm{mSv}$ in 2014 and $0.180 \pm 0.067 \mathrm{mSv}$ in 2004. Model calculations, however, give averted dose equivalents of $0.033 \mathrm{mSv}$ for 2014 and $0.094 \mathrm{mSv}$ for 2004.

The sum of annual mean natural $H^{*}(10)$ contributions from soil in the rest of Slovenia was $0.66 \mathrm{mSv}(21)$, which was constant over time, while the cosmic-ray contribution was about $0.31 \mathrm{mSv}$, which exceeds the measured annual ambient dose equivalents. Therefore, it is not likely that the disagreement between the doses averted by the solar activity originates from an overestimation of the contribution of the charged-particle component of the cosmic rays to the measured ambient dose equivalents, but rather points to an underestimation of the influence of solar activity in EXPACS calculation.

\section{CONCLUSIONS}

Our findings suggest that the contribution of cosmic rays to annual ambient dose equivalent can be easily identified through solar activity. We identified it quantitatively by calculating the correlation between mean annual number of sunspots and annual ambient dose equivalents measured at specific locations. Correlation coefficients turned out to be consistently below zero, implying a clear negative correlation between the two. Quantitative analysis of $H^{*}(10)$ at NPP Krško and the rest of Slovenia has shown that it is averted by solar activity and that the averted $H^{*}(10)$ measured by TL dosimeters exceeds the one calculated with EXPACS when the neutron component is excluded. As dose equivalents measured with TL dosimeters do not exceed the sum of contributions from natural soil radioactivity and the non-neutron component of cosmic rays, this disagreement in averted dose equivalents is owed to an underestimation by model calculations. We therefore believe that the only fluctuation in annual dose equivalents is owed to changes in solar activity (solar cycles), as Chernobyl contamination is no longer an influence.

\section{REFERENCES}

1. EUR-Lex. Consolidated version of the Treaty establishing the European Atomic Energy Community. OJEU 2012/C/237/01 [displayed 11 January 2021]. Available at https://eur-lex.europa.eu/eli/treaty/euratom_2012/oj

2. International Atomic Energy Agency (IAEA). Environmental and Source Monitoring for Purposes of Radiation Protection. IAEA Safety Standards for protecting people and the environment. Safety Guide No. RS-G-1.8. Vienna: IAEA; 2005.

3. Sokić A, Perazić L, Knežević I. Measurement of the ambient dose equivalent $H^{*}(10)$ in the surrounding of nuclear facilities in Serbia. RAD Conf Proc 2018;3:42-6. doi: 10.21175/ RadProc.2018.09

4. SURO National Radiation Protection Institute. TLD Territorial Network [displayed 11 January 2021]. Available at https://www.suro.cz/en/rms/tld

5. Sáez-Vergara JC, Romero AM, Vila Pena M, Rodriguez R, Muñiz JL. The use of passive TLDs in operation of the Spanish early warning network 'REVIRA'. Radiat Prot Dosimetry 2002;101:249-52. doi: 10.1093/oxfordjournals. rpd.a005978

6. Zorko B, Knežević Ž, Črnič B, Majer M, Ranogajec-Komor M. A transnational intercomparison of environmental dosemeters in realistic environmental conditions. Radiat Prot Dosimetry 2017;174:287-90. doi: 10.1093/rpd/ncw109 
7. Pravilnik o monitoringu radioaktivnosti (JV 10) [Rules on the monitoring of radioactivity (JV 10), in Slovene]. Uradni list RS 27/2018.

8. Zakon o varstvu pred ionizirajočimi sevanji in jedrski varnosti (ZVISJV-1) [Ionising radiation protection and nuclear safety act (ZVISJV-1), in Slovene]. Uradni list RS 76/2017.

9. Grupen Claus. Secondary cosmic rays. In: Astroparticle physics. Undergraduate texts in Physics. $2^{\text {nd }}$ ed. Springer International Publishing 2020. p. 235-91. doi: 10.1007/9783-030-27339-2

10. Fujinami N. Observational study of the scavenging of radon daughters by precipitation from the atmosphere. Environ Int 1996:22(Suppl 1):S181-5. doi: 10.1016/S01604120(96)00106-7

11. Bottardi C, Alberi M, Baldocini M, Chiarellia E, Montuschi M, Raptisac KGC, Serafini A, Strati V, Mantovani F. Rain rate and radon daughters' activity. Atmos Environ 2020;238:11728. doi: 10.1016/j.atmosenv.2020.117728

12. Maseryk J, Beer J. Simulation of particle fluxes and cosmic nuclide productions in earth's atmosphere. J Geophys Res 1999;104:12099-112. doi: 10.1029/1998JD200091

13. WDC-SILSO, World Data Center for the production, preservation and dissemination of the international sunspot number. Royal observatory of Belgium [displayed 11 January 2021]. Available at http://www.sidc.be/silso/datafiles

14. Zorko B, Miljanić S, Vekić B, Štuhec M, Gobec S, RanogajecKomor M. Intercomparison of dosimetry systems based on $\mathrm{CaF}_{2}: \mathrm{Mn} \mathrm{TL}$ detectors. Radiat Prot Dosimetry 2006;119:300 5. doi: $10.1093 / \mathrm{rpd} / \mathrm{nci} 640$
15. Štuhec M, Zorko B, Vekić B, Miljanić S, Bašić B, Ban R. Harmonization of individual dosimetry quality control within metrology system of a small country. Radiat Prot Dosimetry 2008;125(1-4):117-20. doi: 10.1093/rpd/ncm198

16. NEK - Nuklearna elektrana Krško. [Letno poročilo o meritvah radioaktivnosti v okolju, in Slovene] [displayed 11 January 2021]. Available at https://www.nek.si/s1/novinarskosredisce/porocila/letno-porocilo-o-meritvah-radioaktivnostiv-okolju

17. Sato T. Analytical model for estimating terrestrial cosmic ray fluxes nearly anytime and anywhere in the world: Extension of PARMA/EXPACS. PLoS One 2015;10(12):e0144679. doi: 10.1371/journal.pone.0144679

18. Sato T. Analytical model for estimating the zenith angle dependence of terrestrial cosmic ray fluxes. PLoS One 2016;11(8):e0160390. doi: 10.1371/journal.pone.0160390

19. EXPACS - Excel-based Program for calculating Atmospheric Cosmic-ray Spectrum [displayed 11 January 2021]. Available at http://phits.jaea.go.jp/expacs/

20. Andjelov M, Brajnik D. Time evolution of the Chernobyl Caesium contamination in Slovenian soils. In: The second Regional Mediterranean Congress on Radiation Protection; 16-20 Nov 1997; Tel-Aviv, Israel. Program and extended abstracts 1997. p. 302-5.

21. Brajnik D, Miklavžič U, Tomšič J. Map of the natural radioactivity in Slovenia and its correlation to the emanation of radon. Radiat Prot Dosimetry 1992;45:273-6. doi: $10.1093 / \mathrm{rpd} / 45.1-4.277$

Vpliv sončne aktivnosti na okoljski dozni ekvivalent $H^{*}(10)$ v Sloveniji merjen s termoluminiscenčnimi dozimetri

Okoljski dozni ekvivalent $H^{*}(10)$ merimo, da ocenimo izpostavljenost populacije ionizirajočemu sevanju. Iz časovne in prostorske odvisnosti je mogoče ugotoviti vire izpostavljenosti. Polletne dozne ekvivalente $H^{*}(10)$ merimo rutinsko s termoluminiscenčmimi dozimetri na 66 lokacijah v okolici Jedrske elektrarne Krško (NEK) in na 50 drugih lokacijah na teritoriju Slovenije. Ker kontaminacija zaradi Černobilske nesreče ne prispeva več k okoljskemu doznemu ekvivalentu smo izračunali korelacijske koeficiente med povprečnim letnim številom sončnih peg in letnim $H^{*}(10)$. Korelacijske koeficiente smo izračunali za pet lokacij v Zahodni Sloveniji in pet lokacij v bližini NEK. Vrednosti korelacijskih koeficientov so $v$ intervalu od -0.64 do -0.38 , kar kaže na močno korelacijo med sončno aktivnostjo in $\mathrm{H}^{*}(10)$. Zaradi sončeve aktivnosti so bili povprečni letni $\mathrm{H}^{*}(10)$ v zadnjih dveh sončnih maksimumih zmanjšani za $0.070 \mathrm{mSv}$ v okolici NEK (na nadmorski višini $155 \mathrm{~m}$ ) in za $0.132 \mathrm{mSv}$ in $0.180 \mathrm{mSv}$ na Kredarici (na nadmorski višini $2515 \mathrm{~m}$ ). Ovrednotenje vpliva sončeve aktivnosti na okoljski dozni ekvivalent boljša razumevanje izpostavljenosti populacije ionizirajočemu sevanju.

KLJUČNE BESEDE: Černobilska kontaminacija; korelacijski koeficient; kozmični žarki; preprečen okoljski dozni ekvivalent; sončni cikel 